\title{
Cost Assessment Modelling of Treatments for Highly Active Relapsing Multiple Sclerosis
}

\author{
Petri Mankinen · Tuomas Lundström • Erkki Soini (D) • \\ Marja-Liisa Sumelahti · Juhani Ruutiainen • Ulla Niskala • \\ Elina Järvinen
}

Received: November 1, 2019 / Published online: December 23, 2019

(c) The Author(s) 2019

\begin{abstract}
Introduction: Cost assessment modelling (CAM) of treatments in highly active relapsing multiple sclerosis was conducted.

Methods: The CAM was developed using the $R$ programming language. The PICOSTEPS health technology assessment framework was applied in the CAM. Modelled patients were 280 adults with highly active relapsing multiple sclerosis eligible for disease-modifying treatment. Intervention was cladribine tablets, a new and reimbursed oral treatment for highly active
\end{abstract}

Petri Mankinen and Tuomas Lundström contributed equally to this article.

Enhanced Digital Features To view enhanced digital features for this article go to https://doi.org/10.6084/ m9.figshare.11295062.

P. Mankinen $(\varangle) \cdot T$. Lundström $\cdot$ E. Soini ESiOR Oy, Tulliportinkatu 2 LT4 70100, Kuopio, Finland

e-mail: petri.mankinen@esior.fi

T. Lundström

e-mail: tuomas.lundstrom@esior.fi

E. Soini

e-mail: erkki.soini@esior.fi

URL: https://www.linkedin.com/in/erkkisoini/

M.-L. Sumelahti

Faculty of Medicine and Health Technology,

Tampere University, 33014-TaY, Tampere, Finland relapsing multiple sclerosis in Finland. Comparators included fingolimod, the most used oral reimbursed treatment for the highly active disease, and natalizumab, the most used intravenous treatment, and a treatment mix $(80 \%$ use fingolimod, 20\% use natalizumab) in Finland. Outcomes presented expected annual and cumulative drug-associated costs in the overall population and per patient. Setting was modelled public specialist care in Finland. Time was set to 4 years, without discounting. Effects covered expected drug-associated costs (screening, acquisition, administration, monitoring, adverse events, travelling, productivity). Perspective was a limited societal perspective. Sensitivity analyses regarding all PICOSTEPS components were conducted.

Results: Cladribine tablets were projected to be cost saving in comparison to fingolimod,

J. Ruutiainen

Finnish Neuro Society, Vaihemäentie 10, 21250

Masku, Finland

J. Ruutiainen

Department of Neurology, University of Turku, PO

Box 52, 20521 Turku, Finland

U. Niskala · E. Järvinen

Merck Finland, Keilaranta 6, 02150 Espoo, Finland

E. Järvinen

Department of Medicine, University of Helsinki,

Haartmaninkatu 8, Haartmaninkatu, 02900

Helsinki, Finland 
natalizumab and treatment mix. The respective modelled savings were $€ 4,598,742, € 16,249,701$ and $€ 6,928,934$ in the overall population, and $€ 16,424, € 58,035$ and $€ 24,746$ per patient, respectively, during the 4 years. The most important cost driver was drug costs, representing $96.3 \%, 96.0 \%$ and $83.4 \%$ of modelled costs associated with cladribine tablets, fingolimod and natalizumab, respectively. Cladribine tablets sustained their affordability in the sensitivity analyses. From the perspective of health care payer, cladribine tablets' savings were projected to be $€ 4,514,509$, $€ 15,145,366$ and $€ 6,640,680$ in the overall population, and $€ 16,123, € 54,091$ and $€ 23,717$ per patient in comparison to fingolimod, natalizumab and treatment mix, respectively.

Conclusion: Based on the CAM, cladribine tablets were projected to robustly save modelled drug-associated costs in comparison to fingolimod, natalizumab and their mix in Finland.

Keywords: Cladribine tablets; Cost; Fingolimod; Multiple sclerosis; Natalizumab; Productivity; Travelling

\section{Key Summary Points}

Why carry out this study?

Multiple sclerosis results in considerable financial burden.

Research of costs in highly active multiple sclerosis is scarce, especially in the Finnish setting.

Drug-related costs of three multiple sclerosis treatments and a treatment mix of fingolimod and natalizumab in highly active relapsing multiple sclerosis were modelled over 4 years in Finland.

\section{What was learned from the study?}

Drug-related costs of cladribine tablets were $€ 71,413$ per patient. The respective per-patient costs for fingolimod, natalizumab and treatment mix were $€ 16,424$; $€ 58,035$; and $€ 24,746$ higher, respectively.
Cladribine tablets were robustly projected to be a cost-saving treatment option compared to fingolimod, natalizumab and their treatment mix in the Finnish setting.

\section{INTRODUCTION}

Multiple sclerosis (MS) is an immune-mediated disorder of the central nervous system with a wide heterogeneity in the clinical course. Most patients are classified as having a relapsing-remitting MS (RRMS) [1], which is further classified as active or highly active, based on the relapse rate and magnetic resonance imaging (MRI) findings [2]. Approximately $4-14 \%$ of all MS patients, depending on the definition used, already have a highly active disease course from the onset [3]. During the disease trajectory, this subgroup of patients is marked by a rapid accumulation of functional deficits and MRI activity, despite treatment with one or more disease-modifying drugs (DMDs) [4].

MS is a leading cause of disability in adults, and requires lifelong treatment $[5,6]$. The average time from MS onset to death is 35 years [7]. There is no cure for MS, but DMDs prevent relapses and delay disease progression [8].

According to the Finnish treatment guidelines, patients eligible to receive a DMD for highly active disease need to show one relapse in the previous year and at least one T1 gadolinium-enhancing lesion or 9 or more T2 lesions while on therapy with a DMD, or two or more relapses in the previous year, whether or not on DMD [9]. Three approved DMDs for the highly active disease are used in Finland: cladribine tablets, fingolimod and natalizumab [10-12]. Cladribine tablets are approved for use for the treatment of adult patients with highly active relapsing MS, including RRMS, and relapsing secondary progressive MS populations [10].

Finland is a high-risk MS region with a prevalence of 280/100,000 in southwest parts of the country [13], and a nationwide prevalence 
estimate between 10,000 and 11,000 patients, corresponding to a crude prevalence of 180-200/100,000 [14]. The estimated annual economic burden of MS in Finland using a bottom-up approach of costing was $€ 46,994$ per patient on average and increasing from $€ 10,835$ to $€ 109,901$ in parallel with advancing disability [15]. Based on a modelled economic evaluation of RRMS patients who have initiated a DMD, effective and reasonably priced DMDs may compensate for various RRMS-related costs in a 15-year time horizon [16]. The impact of MS medication costs on overall healthcare systems has been assessed by per-member per-period costs, where MS represents the fourth most expensive therapy class following inflammatory conditions, diabetes and cancer [17]. In Finland, the estimated proportion of total costs attributable to DMDs is high over 1-year [15] and moderately high (11-18\%, depending on DMD) over 15-year [16] time horizons among RRMS patients who have initiated DMD and were valid for a publicly reimbursed DMD.

The costs and cost-effectiveness of DMDs indicated for highly active disease in Finland have not previously been published. In foreign settings and modelled comparisons, cladribine tablets have been observed to be dominant (i.e. lower cost and higher effectiveness) in various settings: compared to fingolimod in Spanish patients with highly active relapsing disease [18], compared to alemtuzumab and natalizumab in English patients with highly active RRMS [19], and compared to alemtuzumab and fingolimod in patients with highly active RRMS as well as compared to natalizumab in patients with rapidly evolving severe disease in the Dutch setting [20]. A cost assessment model (CAM) was developed to project the costs of DMDs for highly active disease in Finland.

\section{METHODS}

The CAM was developed with the programming language $R$ to project drug-related costs of selected highly active MS therapies based on input parameters described below. The CAM approach was developed for easy and safe estimation of costs over time. To ensure the coverage of important features, PICOSTEPS principle $[16,21-23]$ was applied in the CAM dashboard.

PICOSTEPS (Patients-Intervention-Comparators-Outcomes-Setting-Time-Effects-Perspective-Sensitivity analysis) is a framework for reporting health economic studies. It covers the essential parts of health economic evaluations in their order of importance [16, 21, 23]; (Table 1). PICOSTEPS has been used in multiple Finnish health economic studies and in a Current Care guideline [16, 21, 23].

\section{Patients}

The yearly number of Finnish relapsing MS patients with highly active disease, who initiate DMD or switch from another DMD, is estimated to be approximately 280, based on Finnish reimbursement statistics. Based on this estimation, the size of the modelled patient population was chosen to be 280 .

Patients were modelled to have cladribine tablets $10 \mathrm{mg}$ (cumulative dose $3.5 \mathrm{mg} / \mathrm{kg}$ over 2 years) (intervention), or alternatively (1) fingolimod $0.5 \mathrm{mg}$, (2) natalizumab $300 \mathrm{mg}$ or (3) a treatment mix consisting of $80 \%$ patients using fingolimod and $20 \%$ of patients using natalizumab based on the Finnish clinical practice, and their similar patient populations defined in their summaries of product characteristics [10-12] (comparators). Highly active disease patients are defined by clinical or imaging features according to the Finnish treatment guidelines and reimbursement criteria $[9,24,25]$. Seventy-two percent of patients were women in the model input [16]. Patients were assumed to stay alive until the end of follow-up (4 years).

The analysis was based on modelling, and the data utilized were obtained from previously conducted studies. The study did not include any new studies with human participants or animals performed by any of the authors. Thus, the study was not registered with any clinical trial database. 
Table 1 PICOSTEPS applied in the highly active relapsing MS cost assessment model (CAM) input

\begin{tabular}{|c|c|c|}
\hline $\begin{array}{l}\text { PICOSTEPS } \\
{[16,21-23]}\end{array}$ & Definition & Respective sources \\
\hline \multirow[t]{4}{*}{ P: patients } & Disease: highly active relapsing MS & {$[9-12,24,25]$} \\
\hline & Feasible MS population in Finland: 280 patients & $\begin{array}{l}\text { Sales statistics estimate for dynamic } \\
\text { population }\end{array}$ \\
\hline & Gender: $72 \%$ women & {$[16]$} \\
\hline & Weight: $86.4 \mathrm{~kg}$ male, $72.4 \mathrm{~kg}$ female & {$[26]$} \\
\hline I: intervention & Cladribine tablets & {$[10]$} \\
\hline $\begin{array}{l}\text { C: } \\
\text { comparators }\end{array}$ & $\begin{array}{l}\text { Fingolimod and natalizumab, and a treatment mix ( } 80 \% \text { use } \\
\text { fingolimod, } 20 \% \text { use natalizumab) }\end{array}$ & $\begin{array}{l}\text { [11], Finnish clinical practice for } \\
\text { natalizumab, sales statistics for the } \\
\text { treatment mix }\end{array}$ \\
\hline O: outcomes & $\begin{array}{l}\text { Expected annual and cumulative drug-associated costs, cost } \\
\text { dispersion }\end{array}$ & Rationale: $[27,28]$ \\
\hline S: setting & Modelled specialist care in Finland & [10-12]; clinical practice \\
\hline $\mathrm{T}$ : time & $\begin{array}{l}\text { Four years drug acquisition costs at June } 2019 \text { values, hospital } \\
\text { district tariffs at } 2019 \text { values, other costs at year } 2018 \\
\text { values, no discounting }\end{array}$ & Rationale: $[27,28]$ \\
\hline E: effects & $\begin{array}{l}\text { Drug-associated costs (screening, acquisition, administration, } \\
\text { monitoring, adverse events, travelling, productivity) }\end{array}$ & $\begin{array}{l}\text { SmPCs }[10-12] \text { or clinical practice; see } \\
\text { Tables } 2 \text { and } 3\end{array}$ \\
\hline P: perspective & Drug-related costs (partially societal) & Logical assumption \\
\hline \multirow{15}{*}{$\begin{array}{l}\text { S: sensitivity } \\
\text { analyses }\end{array}$} & P: $50 \%$ or $90 \%$ female & Assumption \\
\hline & $P:$ average age 36 years & {$[16]$} \\
\hline & P: age-weight distribution & {$[26]$} \\
\hline & I: adherence decreases $10 \%$ each year & As above, assumption \\
\hline & C: adherence decreases $10 \%$ each year & Assumption \\
\hline & S: no screening & Assumption \\
\hline & $\mathrm{T}$ : 3-year results & Assumption \\
\hline & E: fingolimod use based on clinical practice & Finnish clinical practice (fingolimod) \\
\hline & E: natalizumab use based on Tysabri SmPC & {$[12]$} \\
\hline & E: natalizumab administration based on Finnish price tariffs & {$[29,30]$} \\
\hline & E: All cost inputs $\pm 20 \%$ & Assumption \\
\hline & $\begin{array}{l}\text { E: fingolimod used after cladribine tablets (sequential } \\
\text { approach) }\end{array}$ & Assumption (risks: [31]) \\
\hline & P: direct costs & {$[32]$} \\
\hline & P: direct costs without travelling costs & [32] \\
\hline & P: drug costs alone & {$[32]$} \\
\hline
\end{tabular}




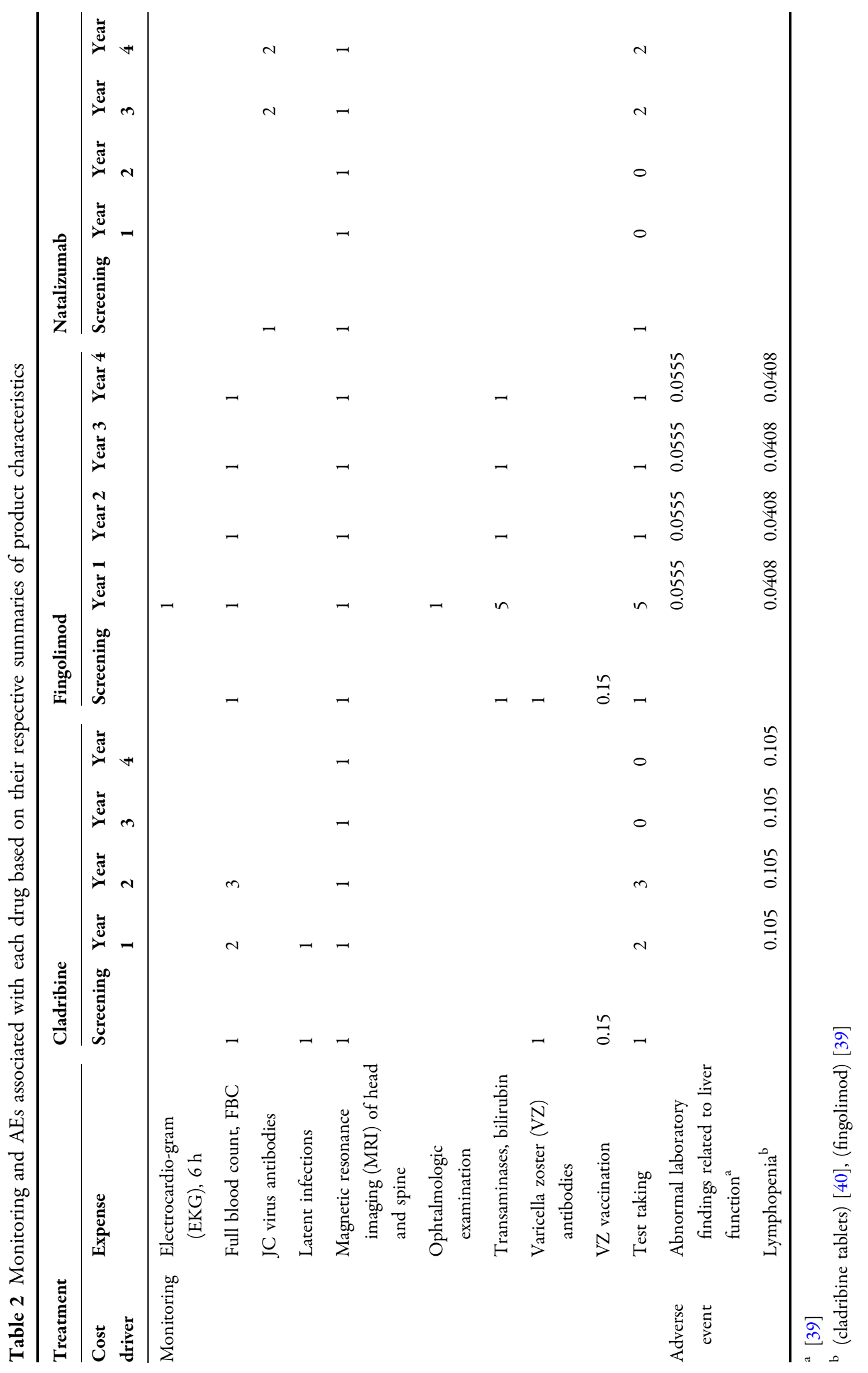


Table 3 Unit costs utilized in the analysis

\begin{tabular}{|c|c|c|c|}
\hline Cost driver & Expense & Cost $(€)$ & Reference \\
\hline \multirow[t]{6}{*}{ Drug acquisition } & Cladribine $10 \mathrm{mg}, 1 \mathrm{tbl}$ & 2433.69 & FMT 06/19 [34] \\
\hline & Cladribine $10 \mathrm{mg}, 4 \mathrm{tbl}$ & 9624.82 & FMT 06/19 [34] \\
\hline & Cladribine $10 \mathrm{mg}, 6 \mathrm{tbl}$ & $14,418.91$ & FMT 06/19 [34] \\
\hline & Fingolimod $0.5 \mathrm{mg} 7 \mathrm{tbl}$ & 427.62 & FMT 06/19 [34] \\
\hline & Fingolimod $0.5 \mathrm{mg} 28 \mathrm{tbl}$ & 1612.99 & FMT 06/19 [34] \\
\hline & Natalizumab $300 \mathrm{mg}$ & 2250.00 & FMT 06/19 [34] \\
\hline \multirow{2}{*}{$\begin{array}{l}\text { Drug } \\
\text { administration }\end{array}$} & Natalizumab $\mathrm{NaCl}$ for infusion & 0.87 & FMT 06/19 [34] \\
\hline & Natalizumab infusion administration ${ }^{\mathrm{e}}$ & 309.82 & [38] indexed to 2018 value $^{a}$ \\
\hline \multirow[t]{10}{*}{ Monitoring } & Electrocardiogram (EKG), $6 \mathrm{~h}^{\mathrm{f}}$ & 587.00 & {$[30]$} \\
\hline & Full blood count, FBC & 4.60 & {$[35]$} \\
\hline & JC virus antibodies & 70.00 & {$[35]$} \\
\hline & Latent infections & 120.53 & {$[35]$} \\
\hline & $\begin{array}{l}\text { Magnetic resonance imaging (MRI) of head and } \\
\text { spine }^{e}\end{array}$ & 320.00 & {$[30]$} \\
\hline & Ophthalmologic examination $^{\mathrm{e}}$ & 215.60 & [36] indexed to 2018 value $^{a}$ \\
\hline & Transaminases, bilirubin & 4.00 & {$[35]$} \\
\hline & Varicella zoster (VZ) antibodies & 20.00 & {$[35]$} \\
\hline & $\mathrm{VZ}_{\text {vaccination }}{ }^{\mathrm{d}}$ & 203.68 & $\begin{array}{l}\text { [36] indexed to } 2018 \text { value }^{a} / F M T \\
6 / 2019[34]\end{array}$ \\
\hline & Test taking $^{\mathrm{d}}$ & 5.52 & [37] indexed to 2018 value $^{a}$ \\
\hline \multirow[t]{2}{*}{ Adverse event } & $\begin{array}{l}\text { Abnormal laboratory findings related to liver } \\
\text { function }^{\mathrm{d}}\end{array}$ & $96.26^{\mathrm{b}}$ & $\begin{array}{l}\text { [36] indexed to } 2018 \text { value }^{\mathrm{a}} \text {, VSSHP } \\
\text { [35] }\end{array}$ \\
\hline & Lymphopenia $^{\mathrm{d}}$ & $226.83^{\mathrm{c}}$ & [36] indexed to 2018 value $^{a},[35]$ \\
\hline \multirow[t]{2}{*}{ Travelling } & Primary care & 7.40 & [37] indexed to 2018 value $^{a}$ \\
\hline & Secondary care & 37.80 & [37] indexed to 2018 value $^{a}$ \\
\hline \multirow[t]{3}{*}{ Productivity loss } & Primary care ( $1 / 4$ day $)$ & 64.24 & [42] indexed to 2018 value $^{a}$ \\
\hline & Secondary care (half a day) & 128.48 & [42] indexed to 2018 value $^{a}$ \\
\hline & Full day & 256.96 & [42] indexed to 2018 value $^{a}$ \\
\hline
\end{tabular}

FMT Finnish Medicines Tariff

${ }^{\text {a }}$ Official Statistics of Finland [41]

b Blood test, specialist paper consultation, specialist telephone consultation, 5\% of patients an additional specialist visit and upper stomach ultrasound

c Lymphocytes differential count, specialist paper consultation, specialist telephone consultation

${ }^{d}$ Productivity loss and travelling cost for this procedure estimated to be $1 / 4$ day

e Productivity loss and travelling cost for this procedure estimated to be $1 / 2$ day

${ }^{\mathrm{f}}$ Productivity loss and travelling cost for this procedure estimated to be full day 


\section{Resources and Costs}

The primary focus on analytical perspective was on drug-related costs. The perspective was partially societal, considering direct drug-related costs, such as drug acquisition and administration costs, monitoring and adverse events (AEs), as well as indirect drug-related costs such as productivity loss (absenteeism) and travelling costs related to the health care resources used. This perspective considers the direct costs to the same extent as the Finnish medicines agency (Fimea) guidelines on the evaluation of hospital products [33].

Drug-associated screening, acquisition, administration (also including infusions where relevant), monitoring, AEs, travelling, and productivity costs (Tables 2 and 3 ) were based on Finnish practices, sources and price tariffs $[16,29,30,34-38]$, and SmPCs [10-12]. Official Finnish list prices of drugs from June 2019 were applied. No treatment pauses or discontinuations were permitted in the base case, but their impact was tested in the sensitivity analyses.

Cladribine tablets were used according to the Mavenclad SmPC, i.e. two annual treatment courses giving a cumulative dose of $3.5 \mathrm{mg} / \mathrm{kg}$ over 2 years and applying $86.4 \mathrm{~kg}$ average weight for men and $72.4 \mathrm{~kg}$ average weight for women (average adult weight in nationally representative FinTerveys study [26]). In sensitivity analyses, age and age-weight distributions were applied to inform the dosing of cladribine tablets [26]. In addition, $24 \%$ of cladribine tablets users were assumed to initiate fingolimod on the fourth year, based on the proportion of relapse-free patients $(76 \%)$ in a CLARITY extension study [31].

Conservatively (i.e. not benefitting cladribine tablets), fingolimod users collected a 7-tablet pack and 13 28-tablet packs from a community pharmacy during the first year of their treatment, and 13 28-tablet packs annually as per label [11], which is the most affordable treatment practice for fingolimod. In the sensitivity analysis, 14 28-tablet packs were assumed to be collected from a community pharmacy during the first year based on the Finnish clinical practice. Since cladribine tablets and fingolimod have restricted reimbursements in
Finland, and they are used in an outpatient setting $[24,25]$, the retail prices of Finnish medicine tariff [34] excluding value added tax (VAT 10\%) were used.

Likewise, natalizumab was conservatively assumed to be administered 12 times per year in a hospital setting based on the Finnish clinical practice and the most affordable treatment practice for natalizumab. In the sensitivity analysis, 14 natalizumab infusions took place during the first year and 13 during subsequent years based on the 28-day dosing interval described in the SmPC [12]. The official wholesale price was used for hospital-administered natalizumab [34] and its administration cost was accrued from a Finnish study [38]. In the sensitivity analyses, two other sources for the administration costs were applied. The administration costs (€934.50 and $€ 373.00$ ) were based on a drug-inclusive administration cost $(€ 2623.00)$ found in the price tariff of the Hospital District of Pirkanmaa, Finland, [29] of which the cost of administration was derived from the total cost by subtracting (1) the official wholesale price of natalizumab dose (€2250.00) and (2) the average drug price of natalizumab $(€ 1688.50)$ found in the price tariff of the hospital district of Uusimaa, Finland [30].

Statistical significance related to risk assessment can be impacted, for example, by assumed statistical power, accrued sample size and follow-up time. Thus, the AEs for CAM were accounted for by annualizing the AE probabilities [43] of clinical trials [39, 40, 44], and by applying an inclusion threshold of $\geq 4 \%$ between the active treatment and placebo in the AE probability [16].

Finally, analytical perspective can have a considerable impact on the outcomes of health economic evaluation (e.g. [16, 21, 45-47]). In this modelled assessment, productivity costs were based on absenteeism due to drug-associated screening, infusions, monitoring, AEs, and travelling. Absenteeism was valued based on the human capital approach using a Finnish valuation. Sensitivity analyses covered different costing perspectives. 


\section{Outcomes}

Primary outcomes included undiscounted modelled annual and cumulative treatment-related costs presented in the overall population of 280 patients and per patient. The cost drivers were defined in year 2018 (unit costs in older than year 2018 values were indexed to the year 2018 real value) and 2019 values. Annual costs were calculated by adding up the cost drivers for each treatment per year, and the cumulative costs by adding up the annual costs and the screening costs for each treatment.

Extensive deterministic sensitivity analyses were conducted for all PICOSTEPS inputs.

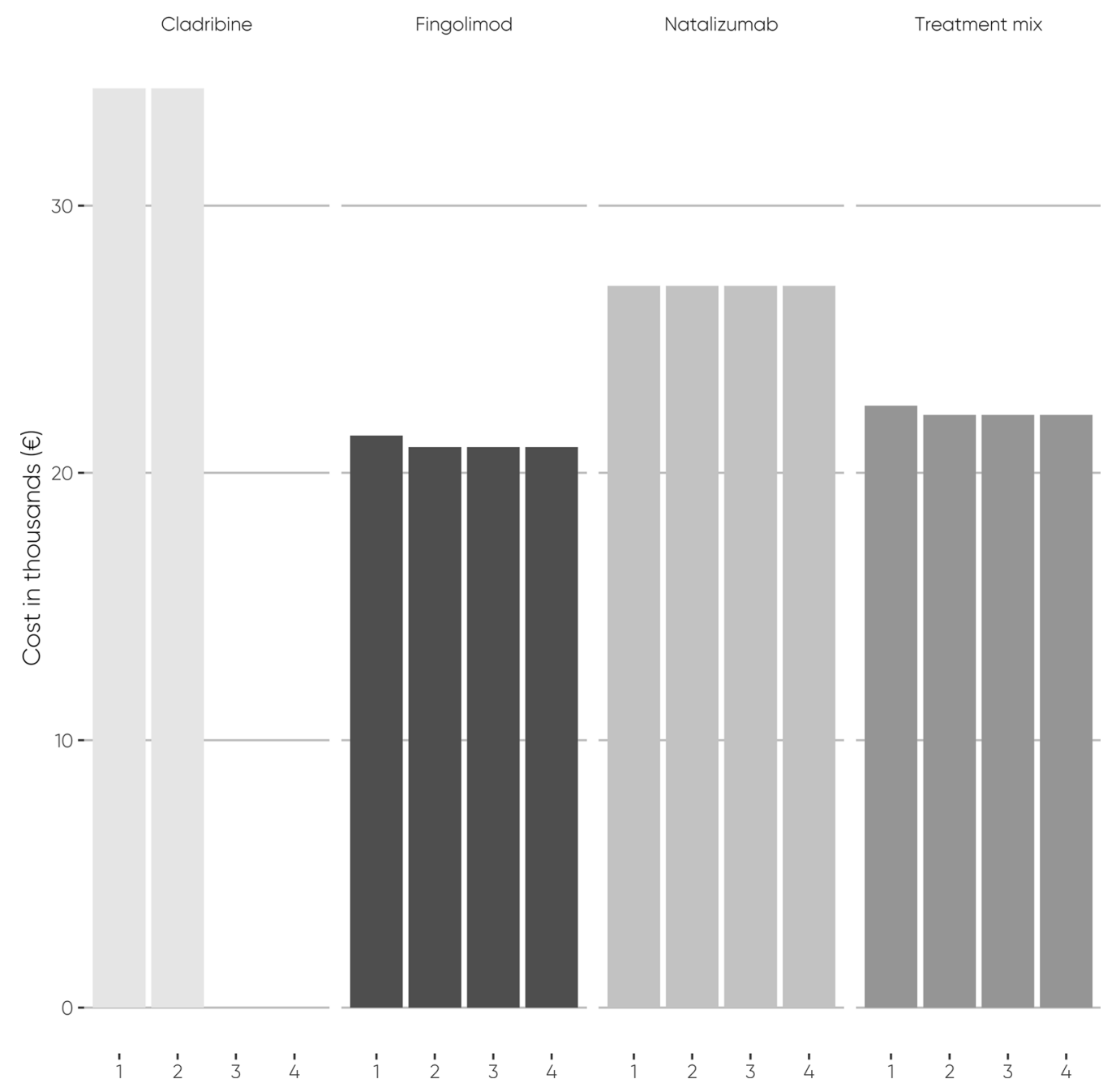

Fig. 1 Annual acquisition costs per patient
Overall, the intervention (cladribine tablets) were projected to reduce the expected drug associated costs in comparison to the comparators (fingolimod, natalizumab, treatment mix) during the 4-year treatment period and associated screening (Figs. 1, 2; Tables 4, 5).

\section{Annual Costs}

Annual modelled costs during the 4-year treatment period were relatively stable for the comparators, but not for cladribine tablets (Figs. 1, 2 ; Tables 4, 5). Cladribine tablets are acquired in

\section{RESULTS}




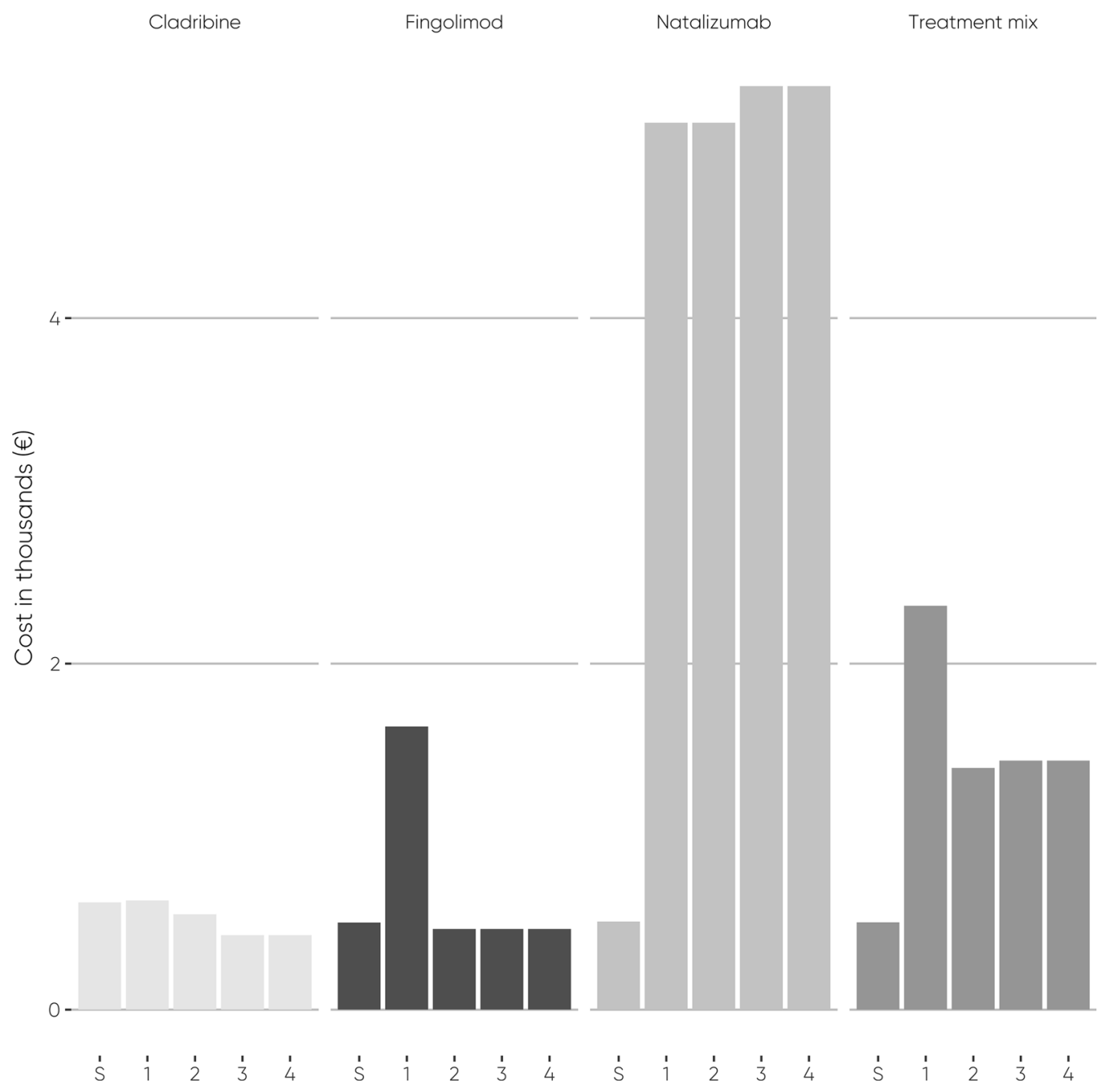

Fig. 2 Drug-associated screening costs, and annual monitoring, administration, AEs, travelling, and productivity costs per patient. $S=$ Screening

the first 2 years, whereas the comparators are acquired continuously.

The modelled total screening costs of cladribine tablets were $€ 619$ per patient and $€ 173,303$ in the overall population. The modelled total screening costs of fingolimod, natalizumab, and treatment mix were $€ 502, € 509$, and $€ 504$ per patient and $€ 140,674, € 142,449$, and $€ 141,029$, respectively, in the overall population.

In the first year, the modelled costs of cladribine tablets were $€ 35,007$ per patient and $€ 9,802,041$ in the population. In comparison, the modelled costs of fingolimod, natalizumab, and the treatment mix were $€ 23,034, € 32,129$, and $€ 24,853$ per patient and $€ 6,449,493$, $€ 8,996,169$, and $€ 6,958,828$ in the overall population, respectively.

The modelled costs in the second year with cladribine tablets were $€ 34,927$ per patient and $€ 9,779,547$ in the overall population. In comparison, the second-year modelled costs of fingolimod, natalizumab, and the treatment mix were $€ 21,434$, $€ 32,129$, and $€ 23,573$ per patient and $€ 6,001,421, € 8,996,169$, and $€ 6,600,370$ in the overall population, respectively.

During the third and fourth years, the modelled drug-associated costs remained unchanged in both years for each treatment. Because cladribine tablets had no drug-acquisition costs 
Table 4 Drug-associated costs $(€)$ per patient

\begin{tabular}{|c|c|c|c|c|c|c|c|}
\hline Drug & Screening & Year 1 & Year 2 & Year 3 & Year 4 & Sum & $\begin{array}{l}\text { Difference to } \\
\text { cladribine }\end{array}$ \\
\hline \multicolumn{8}{|l|}{ Cladribine } \\
\hline Adverse event & 0 & 24 & 24 & 24 & 24 & 95 & NA \\
\hline Drug acquisition & 0 & 34,376 & 34,376 & 0 & 0 & 68,753 & NA \\
\hline Monitoring & 501 & 461 & 350 & 320 & 320 & 1952 & NA \\
\hline Productivity loss & 71 & 93 & 116 & 48 & 48 & 376 & NA \\
\hline Travelling & 46 & 53 & 61 & 39 & 39 & 238 & NA \\
\hline Sum & 619 & 35,007 & 34,927 & 430 & 430 & 71,413 & NA \\
\hline \multicolumn{8}{|l|}{ Fingolimod } \\
\hline Adverse event & 0 & 15 & 15 & 15 & 15 & 58 & -37 \\
\hline Drug acquisition & 0 & 21,396 & 20,969 & 20,969 & 20,969 & 84,303 & 15,550 \\
\hline Monitoring & 385 & 1175 & 334 & 334 & 334 & 2562 & 610 \\
\hline Productivity loss & 71 & 297 & 70 & 70 & 70 & 579 & 203 \\
\hline Travelling & 46 & 151 & 46 & 46 & 46 & 335 & 98 \\
\hline Sum & 502 & 23,034 & 21,434 & 21,434 & 21,434 & 87,837 & 16,424 \\
\hline \multicolumn{8}{|l|}{ Natalizumab } \\
\hline Adverse event & 0 & 0 & 0 & 0 & 0 & 0 & -95 \\
\hline Drug acquisition & 0 & 27,000 & 27,000 & 27,000 & 27,000 & 108,000 & 39,247 \\
\hline Drug administration & 0 & 3728 & 3728 & 3728 & 3728 & 14,913 & 14,913 \\
\hline Monitoring & 396 & 320 & 320 & 471 & 471 & 1978 & 25 \\
\hline Productivity loss & 68 & 590 & 590 & 635 & 635 & 2517 & 2141 \\
\hline Travelling & 45 & 491 & 491 & 506 & 506 & 2040 & 1803 \\
\hline Sum & 509 & 32,129 & 32,129 & 32,340 & 32,340 & 129,448 & 58,035 \\
\hline \multicolumn{8}{|l|}{ Treatment mix } \\
\hline Adverse event & 0 & 12 & 12 & 12 & 12 & 47 & -48 \\
\hline Drug acquisition & 0 & 22,517 & 22,175 & 22,175 & 22,175 & 89,042 & 20,290 \\
\hline Drug administration & 0 & 746 & 746 & 746 & 746 & 2983 & 2983 \\
\hline Monitoring & 387 & 1004 & 331 & 362 & 362 & 2445 & 493 \\
\hline Productivity loss & 71 & 355 & 174 & 183 & 183 & 967 & 591 \\
\hline Travelling & 46 & 219 & 135 & 138 & 138 & 676 & 439 \\
\hline Sum & 504 & 24,853 & 23,573 & 23,615 & 23,615 & 96,159 & 24,746 \\
\hline
\end{tabular}


Table 5 Drug-associated costs $(€)$ in the population

\begin{tabular}{|c|c|c|c|c|c|c|c|}
\hline $\begin{array}{l}\text { Drugs and cost } \\
\text { drivers }\end{array}$ & Screening & Year 1 & Year 2 & Year 3 & Year 4 & Sum & $\begin{array}{l}\text { Difference to } \\
\text { cladribine }\end{array}$ \\
\hline \multicolumn{8}{|l|}{ Cladribine } \\
\hline Adverse event & 0 & 6637 & 6637 & 6637 & 6637 & 26,548 & NA \\
\hline Drug acquisition & 0 & $9,625,384$ & $9,625,384$ & 0 & 0 & $19,250,767$ & NA \\
\hline Monitoring & 140,337 & 129,016 & 98,102 & 89,600 & 89,600 & 546,655 & NA \\
\hline Productivity loss & 20,001 & 26,062 & 32,411 & 13,363 & 13,363 & 105,200 & NA \\
\hline Travelling & 12,965 & 14,942 & 17,013 & 10,799 & 10,799 & 66,519 & NA \\
\hline Sum & 173,303 & $9,802,041$ & $9,779,547$ & 120,399 & 120,399 & $19,995,689$ & NA \\
\hline \multicolumn{8}{|l|}{ Fingolimod } \\
\hline Adverse event & 0 & 4074 & 4074 & 4074 & 4074 & 16,295 & $-10,253$ \\
\hline Drug acquisition & 0 & $5,991,017$ & $5,871,284$ & $5,871,284$ & $5,871,284$ & $23,604,868$ & $4,354,101$ \\
\hline Monitoring & 107,708 & 328,946 & 93,554 & 93,554 & 93,554 & 717,316 & 170,662 \\
\hline Productivity loss & 20,001 & 83,153 & 19,657 & 19,657 & 19,657 & 162,125 & 56,925 \\
\hline Travelling & 12,965 & 42,304 & 12,853 & 12,853 & 12,853 & 93,826 & 27,308 \\
\hline Sum & 140,674 & $6,449,493$ & $6,001,421$ & $6,001,421$ & $6,001,421$ & $24,594,430$ & $4,598,742$ \\
\hline \multicolumn{8}{|l|}{ Natalizumab } \\
\hline Adverse event & 0 & 0 & 0 & 0 & 0 & 0 & $-26,548$ \\
\hline Drug acquisition & 0 & $7,560,000$ & $7,560,000$ & $7,560,000$ & $7,560,000$ & $30,240,000$ & $10,989,233$ \\
\hline Drug administration & 0 & $1,043,902$ & $1,043,902$ & $1,043,902$ & $1,043,902$ & $4,175,607$ & $4,175,607$ \\
\hline Monitoring & 110,746 & 89,600 & 89,600 & 131,892 & 131,892 & 553,730 & 7075 \\
\hline Productivity loss & 19,049 & 165,089 & 165,089 & 177,788 & 177,788 & 704,801 & 599,602 \\
\hline Travelling & 12,654 & 137,578 & 137,578 & 141,721 & 141,721 & 571,252 & 504,733 \\
\hline Sum & 142,449 & $8,996,169$ & $8,996,169$ & $9,055,302$ & $9,055,302$ & $36,245,390$ & $16,249,701$ \\
\hline \multicolumn{8}{|l|}{ Treatment mix } \\
\hline Adverse event & 0 & 3259 & 3259 & 3259 & 3259 & 13,036 & $-13,512$ \\
\hline Drug acquisition & 0 & $6,304,814$ & $6,209,027$ & $6,209,027$ & $6,209,027$ & $24,931,894$ & $5,681,127$ \\
\hline Drug administration & 0 & 208,780 & 208,780 & 208,780 & 208,780 & 835,121 & 835,121 \\
\hline Monitoring & 108,316 & 281,077 & 92,763 & 101,221 & 101,221 & 684,599 & 137,944 \\
\hline Productivity loss & 19,811 & 99,540 & 48,743 & 51,283 & 51,283 & 270,660 & 165,460 \\
\hline Travelling & 12,903 & 61,359 & 37,798 & 38,626 & 38,626 & 189,312 & 122,793 \\
\hline Sum & 141,029 & $6,958,828$ & $6,600,370$ & $6,612,197$ & $6,612,197$ & $26,924,622$ & $6,928,934$ \\
\hline
\end{tabular}


in the third and fourth years, the modelled costs of cladribine tablets plummeted by $99 \%$ to $€ 430$ per patient and $€ 120,399$ in the overall population per year. The modelled costs of fingolimod remained the same as during the second year. Modelled natalizumab costs increased by $0.7 \%$ compared to the first and second years and rose to $€ 32,340$ per patient and to $€ 9,055,302$ in the overall population per year, due to JC virus antibody testing and associated blood sampling, travelling, and productivity loss. The increase of modelled natalizumab costs also increased the total cost of the treatment mix compared to the second year of the treatment period by $0.2 \%$ to $€ 23,615$ per patient and to $€ 6,612,197$ in the overall population per year.

Over the 4-year treatment period, the average modelled annual costs were $€ 17,699$ for cladribine tablets, $€ 21,834$ for fingolimod, $€ 32,235$ for natalizumab and $€ 23,914$ for treatment mix. Consequently, cladribine tablets were projected to save $19-45 \%$ on the average annual drug-associated costs in comparison to the comparators.

\section{Cumulative Costs}

During the 4-year treatment period, cladribine tablets were found to have lower costs than the comparators in terms of cumulative modelled costs (Tables 4, 5). The modelled cumulative costs for the 4 years including screening were: cladribine tablets $€ 71,413$ per patient and $€ 19,995,689$ in the overall population of 280 patients, fingolimod $€ 87,837$ per patient and $€ 24,594,430$ in the overall population, natalizumab $€ 129,448$ per patient and $€ 36,245,390$ in the overall population, and treatment mix $€ 96,159$ per patient and $€ 26,924,622$ in the overall population. The largest difference for the cumulative costs in the overall population compared to cladribine tablets was with natalizumab ( $€ 58,035$ per patient, $€ 16,249,701$ in the overall population; $81 \%$ difference in the cumulative costs), the second largest with the treatment mix ( $€ 24,746$ per patient, $€ 6,928,934$ in the overall population; $35 \%$ difference), and the smallest difference was with fingolimod
$(€ 16,424$ per patient, $€ 4,598,742$ in the overall population; $23 \%$ difference).

Comparison of modelled cost drivers between the treatments demonstrates the comparative affordability of cladribine tablets (Tables 4, 5). The modelled cost of cladribine tablets' drug acquisition, monitoring, productivity loss, and travelling was the most affordable. The modelled cost of AEs with natalizumab was the most affordable. Because cladribine tablets and fingolimod are used orally without administration in the health care setting, only natalizumab and the treatment mix have administration costs. Tables 4 and 5 show the differences between the treatments per cost driver.

The most important cost drivers were drugacquisition costs. The drug-acquisition costs represented $96.3 \%, 96.0 \%, 83.4 \%$ and $92.6 \%$ of modelled costs associated with cladribine tablets, fingolimod, natalizumab and treatment mix, respectively.

\section{Sensitivity Analyses}

Cladribine tablets remained affordable in the extensive sensitivity analyses (Tables 6,7 ) with the 4-year time horizon.

The only analysis scenario where cladribine tablets were not the most affordable treatment alternative was the time horizon of 3 years, where fingolimod was $€ 4580$ less costly per patient and $€ 1,282,280$ less costly in the overall population and compared to cladribine tablets.

Cladribine tablets remained affordable after assuming subsequent treatment with fingolimod in the fourth year for a proportion (24\%) of patients. The modelled cost of cladribine tablets was $€ 76,959$ per patient and $€ 21,548,433$ in the overall population. The savings were $€ 10,879, € 52,489$, and $€ 19,201$ per patient and $€ 3,045,997, € 14,696,957$, and $€ 5,376,189$ in the overall population in comparison to fingolimod, natalizumab, and treatment mix, respectively.

From the perspective of health care payer alone, cladribine tablets' modelled savings were projected to be $€ 16,123, € 54,091$ and $€ 23,717$ per patient and $€ 4,514,509, € 15,145,366$ and $€ 6,640,680$ in the overall population in 
Table 6 Per-patient results of the sensitivity analyses covering all PICOSTEPS components $(€)$

\begin{tabular}{|c|c|c|c|c|}
\hline Analysis & $\begin{array}{l}\text { Cladribine } \\
\text { tablets }\end{array}$ & $\begin{array}{l}\text { Fingolimod } \\
\text { (difference to } \\
\text { cladribine tablets) }\end{array}$ & $\begin{array}{l}\text { Natalizumab } \\
\text { (difference to } \\
\text { cladribine tablets) }\end{array}$ & $\begin{array}{l}\text { Treatment mix } \\
\text { (difference to } \\
\text { cladribine tablets) }\end{array}$ \\
\hline Base case & 71,413 & 16,424 & 58,035 & 24,746 \\
\hline $50 \%$ of patients women & 72,468 & 15,369 & 56,980 & 23,691 \\
\hline $90 \%$ of patients women & 70,550 & 17,287 & 58,898 & 25,609 \\
\hline Age of the population 36 years & 72,585 & 15,252 & 56,863 & 23,574 \\
\hline $\begin{array}{l}\text { Patient weight based on Finnish real-life } \\
\text { distribution instead of on an average }\end{array}$ & 72,065 & 15,772 & 57,382 & 24,094 \\
\hline $\begin{array}{l}\text { Annual adherence drop } 10 \% \text { after } 1 \text { st } \\
\text { year }\end{array}$ & 67,976 & 7280 & 43,035 & 14,431 \\
\hline No screening costs & 70,794 & 16,541 & 58,145 & 24,861 \\
\hline Time horizon 3 years & 70,983 & -4580 & 26,124 & 1561 \\
\hline $\begin{array}{l}\text { Fingolimod utilization: } 14 \text { 28-tablet } \\
\text { packs during the } 1 \text { st year, } 13 \text { packs } \\
\text { thereafter }\end{array}$ & 71,413 & 17,609 & 58,035 & 25,694 \\
\hline $\begin{array}{l}\text { Natalizumab utilization: } 14 \\
\text { administrations during the 1st year, } \\
13 \text { administrations thereafter }\end{array}$ & 71,413 & 16,424 & 71,254 & 27,390 \\
\hline $\begin{array}{l}\text { Cost of natalizumab administration } \\
€ 934.50\end{array}$ & 71,413 & 16,424 & 88,020 & 30,743 \\
\hline $\begin{array}{l}\text { Cost of natalizumab administration } \\
€ 373.00\end{array}$ & 71,413 & 16,424 & 61,068 & 25,353 \\
\hline All cost inputs $-20 \%$ & 57,131 & 13,139 & 46,428 & 19,797 \\
\hline All cost inputs $+20 \%$ & 85,696 & 19,709 & 69,642 & 29,695 \\
\hline $\begin{array}{l}24 \% \text { of cladribine users assumed to } \\
\text { switch to fingolimod on the fourth } \\
\text { year }\end{array}$ & 76,959 & 10,879 & 52,489 & 19,201 \\
\hline Direct costs only & 71,037 & 16,221 & 55,893 & 24,155 \\
\hline Direct costs only, no travelling costs & 70,800 & 16,123 & 54,091 & 23,717 \\
\hline
\end{tabular}

comparison to fingolimod, natalizumab and treatment mix, respectively.

\section{DISCUSSION}

Our CAM-based modelled study of DMD-associated costs demonstrates that cladribine tablets are a cost-saving treatment alternative for patients with highly active relapsing MS compared to fingolimod and natalizumab in the Finnish setting. The average 4-year modelled cost difference of drug-associated costs was $€ 16,424$ per patient compared to fingolimod, $€ 58,035$ compared to natalizumab, and $€ 24,746$ compared to treatment mix. In the overall 
Table 7 Per-population results of the sensitivity analysis covering all PICOSTEPS components $(€)$

\begin{tabular}{|c|c|c|c|c|}
\hline Analysis & $\begin{array}{l}\text { Cladribine } \\
\text { tablets }\end{array}$ & $\begin{array}{l}\text { Fingolimod } \\
\text { (difference to } \\
\text { cladribine tablets) }\end{array}$ & $\begin{array}{l}\text { Natalizumab } \\
\text { (difference to } \\
\text { cladribine tablets) }\end{array}$ & $\begin{array}{l}\text { Treatment mix } \\
\text { (difference to } \\
\text { cladribine tablets) }\end{array}$ \\
\hline Base case & $19,995,689$ & $4,598,742$ & $16,249,701$ & $6,928,934$ \\
\hline $50 \%$ of patients women & $20,291,004$ & $4,303,427$ & $15,954,386$ & $6,633,619$ \\
\hline $90 \%$ of patients women & $19,754,067$ & $4,840,363$ & $16,491,322$ & $7,170,555$ \\
\hline Age of the population 36 years & $20,323,777$ & $4,270,654$ & $15,921,613$ & $6,600,845$ \\
\hline $\begin{array}{l}\text { Patient weight based on Finnish real-life } \\
\text { distribution }\end{array}$ & $20,178,296$ & $4,416,134$ & $16,067,093$ & $6,746,326$ \\
\hline $\begin{array}{l}\text { Annual adherence drop } 10 \% \text { after } 1 \text { st } \\
\text { year }\end{array}$ & $19,033,150$ & $2,038,510$ & $12,049,898$ & $4,040,788$ \\
\hline No screening costs & $19,822,386$ & $4,631,370$ & $16,280,555$ & $6,961,207$ \\
\hline Time horizon 3 years & $19,875,290$ & $-1,282,280$ & $7,314,798$ & 437,136 \\
\hline $\begin{array}{l}\text { Fingolimod utilization: } 14 \text { 28-tablet } \\
\text { packs during the } 1 \text { st year, } 13 \text { packs } \\
\text { thereafter }\end{array}$ & $19,995,689$ & $4,930,645$ & $16,249,701$ & $7,194,456$ \\
\hline $\begin{array}{l}\text { Natalizumab utilization: } 14 \\
\text { administrations during the } 1 \text { st year, } \\
13 \text { administrations thereafter }\end{array}$ & $19,995,689$ & $4,598,742$ & $19,951,070$ & $7,669,207$ \\
\hline $\begin{array}{l}\text { Cost of natalizumab administration } \\
€ 934.50\end{array}$ & $19,995,689$ & $4,598,742$ & $24,645,460$ & $8,608,085$ \\
\hline $\begin{array}{l}\text { Cost of natalizumab administration } \\
€ 373.00\end{array}$ & $19,995,689$ & $4,598,742$ & $17,098,900$ & $7,098,773$ \\
\hline All cost inputs $-20 \%$ & $15,996,551$ & $3,678,993$ & $12,999,761$ & $5,543,147$ \\
\hline All cost inputs $+20 \%$ & $23,994,826$ & $5,518,490$ & $19,499,641$ & $8,314,720$ \\
\hline $\begin{array}{l}24 \% \text { of cladribine users assumed to } \\
\text { switch to fingolimod on the fourth } \\
\text { year }\end{array}$ & $21,548,433$ & $3,045,997$ & $14,696,957$ & $5,376,189$ \\
\hline Direct costs only & $19,890,489$ & $4,541,817$ & $15,650,099$ & $6,763,473$ \\
\hline Direct costs only, no travelling costs & $19,823,970$ & $4,514,509$ & $15,145,366$ & $6,640,680$ \\
\hline
\end{tabular}

population of 280 patients, the respective drugassociated cost differences to cladribine tablets were $€ 4,598,742$, $€ 16,249,701$, and $€ 6,928,934$. The most important cost drivers of modelling were drug-acquisition costs, which accrued $96.3 \%$ of the total costs for cladribine tablets, $96.0 \%$ for fingolimod, $83.4 \%$ for natalizumab, and $92.6 \%$ for treatment $\mathrm{mix}$, and drug administration for natalizumab, which was the only intravenous drug in the study.

Cladribine tablets were also cost saving in all sensitivity analyses with a 4-year time horizon, even when assuming a sequential approach. These findings are supported by cost estimates from other settings [18-20]. The only exception was with the 3 -year time horizon, in which 
fingolimod was $€ 4580$ less costly per patient and $€ 1,282,280$ less costly in the overall population compared to cladribine tablets.

As in all health economic modelling, the results of the present study are subject to uncertainty. Although progressive multifocal leukoencephalopathy (PML) is a severe adverse event associated with natalizumab, and to a lesser extent also with other MS drugs [48], the treatment-related risk of PML in MS is still very low [49]. Due to the high uncertainty in the PML incidence data in clinical trials, it was not considered in our analyses. The total cost of natalizumab, therefore, can be an underestimate.

In addition, we did not include MS relapses in the analysis, despite their impact on costs based on Finnish real-world evidence [16], due to the lack of sufficiently comparable evidence regarding relapse incidence. However, as the cost of relapse is likely to be relatively low (€1316 for events not requiring hospitalization and $€ 5619$ for events requiring hospitalization [16]) compared to the total costs observed in the present study, the impact of relapses as AEs on the results would most likely have been low.

The inclusion of decreased persistence over time resulted in a decrease in the drug-acquisition and administration costs, and the decrease was more profound in drugs that were used for the whole 4 years, i.e. fingolimod and natalizumab. As the present analysis considered only drug-related costs, decreased persistence narrowed the cost gap between cladribine and comparators, although cladribine tablets remained the most affordable.

In addition, persistence does not only affect costs but also the treatment effects, which were outside the scope of this study. Therefore, the interpretation of the effect of persistence on the results does not reflect cost-effectiveness results.

Furthermore, the inclusion of costs related to disease progression (disability) could have had a significant impact on the total costs (see, e.g., [16]). However, their inclusion would have been complicated and most likely given unreliable results, as there are no direct randomised comparisons between cladribine tablets, fingolimod and natalizumab. However, cladribine tablets have demonstrated a comparable efficacy with other DMDs for highly active disease in recent indirect comparison analyses [50-52]. Thus, speculatively, the inclusion of treatment effects could have even increased the affordability of cladribine tablets.

In systematic reviews, indirect comparisons, health economic analyses and models, systematic reporting is especially important $[21,50]$. PICO is commonly applied in, e.g., evidence synthesis and Finnish current care treatment guidelines. Here, we applied an extended version of PICO (PICOSTEPS) $[16,21]$ in order to improve the readability of CAM and these results, and to present the core components of CAM. PICOSTEPS has previously been successfully applied in various health economic evaluations [16, 21-23, 46, 47, 53-56], and in realworld data-based predictive cost-effectiveness and cost-benefit assessments of first-line RRMS treatments [16].

In Finland, the prices of hospital-administered drugs may be confidentially negotiated (tendered) by the hospital, which may lead to lower drug costs paid by the hospital than the official drug price list suggests. On the other hand, this may lead to an underestimation of administration costs. As some hospitals' price tariff lists provide a single cost per administration visit (i.e. including both the administration and the drug), the proportion of administration may be higher than that observed by subtracting the official list price from the total cost of the administration visit.

The present study did not address the effectiveness or cost-effectiveness of the treatments, and nor did it include costs related to effectiveness. This was the main limitation of the study. Therefore, further studies are needed to provide this information, and to gain a more complete understanding of the potential of the different treatments.

\section{CONCLUSION}

Among patients with highly active relapsing MS, cladribine tablets are projected to robustly save expected drug-associated costs in comparison to fingolimod, natalizumab and their mix in Finland. 


\section{ACKNOWLEDGEMENTS}

Funding. Sponsorship, and the journal's Rapid Service fee and Open Access charge for this study were funded by Merck Finland, Espoo, Finland, an affiliate of Merck KGaA, Darmstadt, Germany.

Authorship. All named authors meet the International Committee of Medical Journal Editors (ICMJE) criteria for authorship for this manuscript: study: management (ES, UN), conceptualization (UN, ES, EJ, MLS, JR), design (all); data: acquisition and interpretation (all); analysis: design (all), implementation (TL, ES, PM), interpretation (all); manuscript: initial drafting (ES, PM, TL), critical revision (all), final approval (all), all authors take responsibility for the integrity of the work as a whole, and all of them have given final approval for the version to be published. PM is the guarantor. PM and TL had full access to all of the data in this study and take complete responsibility for the integrity of the data and the accuracy of the data analysis.

Disclosures. Petri Mankinen is an employee of EsiOR Oy, Kuopio, Finland, but does not hold drug company shares. Tuomas Lundström is an employee of EsiOR Oy, Kuopio, Finland, but does not hold drug company shares. Erkki Soini is an employee of ESiOR Oy, Kuopio, Finland, and is also a shareholder, board member and the CEO of ESiOR Oy. EsiOR carries out studies, statistical analysis, consultancy, education, reporting, health economic evaluations and market access services for several pharmaceutical, food industry, diagnostics and device companies, hospitals, consultancies, academic institutions and projects, including the producers and marketers of MS treatments. However, they do not hold drug company shares. Marja-Liisa Sumelahti is an employee at Suomen Terveystalo, Finland, and a Senior Lecturer in Neurology at Tampere University, Finland. Juhani Ruutiainen is an employee of Finnish Neuro Society, Masku, Finland, and a Senior Lecturer in Neurology at the University of Turku, Turku, Finland. The Finnish Neuro Society looks after the interest of people with
MS and rare neurological diseases. Ulla Niskala is an employee of Merck Finland, Espoo Finland, an affiliate of Merck KGaA, Darmstadt, Germany. Elina Järvinen is an employee of Merck Finland, Espoo Finland, an affiliate of Merck KGaA, Darmstadt, Germany. All authorship decisions were based on scientific considerations.

Compliance with Ethics Guidelines. The analysis in this article is based on previously conducted studies and does not involve any new studies of human or animal subjects performed by any of the authors.

Data Availability. All data generated or analysed during this study are included in this published article.

Open Access. This article is licensed under a Creative Commons Attribution-NonCommercial 4.0 International License, which permits any non-commercial use, sharing, adaptation, distribution and reproduction in any medium or format, as long as you give appropriate credit to the original author(s) and the source, provide a link to the Creative Commons licence, and indicate if changes were made. The images or other third party material in this article are included in the articleã $s$ Creative Commons licence, unless indicated otherwise in a credit line to the material. If material is not included in the articleã s Creative Commons licence and your intended use is not permitted by statutory regulation or exceeds the permitted use, you will need to obtain permission directly from the copyright holder. To view a copy of this licence, visit http://creativecom mons.org/licenses/by-nc/4.0/.

\section{REFERENCES}

1. Compston A, Coles A. Multiple sclerosis. Lancet. 2008;372(9648):1502-17.

2. Lublin FD, Reingold SC, Cohen A, et al. Defining the clinical course of multiple sclerosis. Neurology. 2014;83:278-86. 
3. Menon S, Shirani A, Zhao Y, et al. Characterising aggressive multiple sclerosis. J Neurol Neurosurg Psychiatry. 2013;84(11):1192-8.

4. Diaz C, Zarco LA, Rivera DM. Highly active multiple sclerosis: an update. Mult Scler Relat Disord. 2019;30:215-24.

5. Kaye HS, Kang T, LaPlante MP Mobility device use in the United States: disability statistics report 14. June 2000. https://files.eric.ed.gov/fulltext/ ED444296.pdf. Accessed 12 Feb 12, 2018.

6. Cahill A, Fredine H, Zilberman L (2008) Initial briefing: prevalence of paralysis including spinal cord injuries in the United States. April 21, 2009. http://cdd.unm.edu/dhpd/pdfs/InitialBriefing32609. pdf Accessed 3 Feb 2018.

7. Degenhardt A, Ramagopalan SV, Scalfari A, Ebers GC. Clinical prognostic factors in multiple sclerosis: a natural history review. Nat Rev Neurol. 2009;5: 672.

8. Torkildsen $\varnothing$, Myhr KM, Bø L. Disease-modifying treatments for multiple sclerosis-a review of approved medications. Eur J Neurol. 2016;23(Suppl $1): 18-27$.

9. Multiple Sclerosis. Current Care Guidelines. Working group set up by the Finnish medical society Duodecim and the Finnish neurological society. Helsinki: The Finnish medical society Duodecim, 2019. www.kaypahoito.fi. Accessed 15 May 2019.

10. European medicines agency. Mavenclad [Summary of product characteristics], 2017. Available at https:// www.ema.europa.eu/en/documents/product-infor mation/mavenclad-epar-product-information_en. pdf. Accessed 12 June 2019.

11. European medicines agency. Gilenya [Summary of product characteristics], 2011. Available at https:// www.ema.europa.eu/en/documents/productinformation/gilenya-epar-product-information_en. pdf. Accessed 12 June 2019.

12. European medicines agency. Tysabri [Summary of product characteristics], 2006. Available at https:// www.ema.europa.eu/en/documents/productinformation/tysabri-epar-product-information_en. pdf. Accessed 12 June 2019.

13. Pirttisalo AL, Soilu-Hänninen M, Sipilä JOT. Multiple sclerosis epidemiology in Finland: regional differences and high incidence. Acta Neurol Scand. 2019;139(4):353-9.

14. Laakso SM, Viitala M, Kuusisto H, et al. Multiple sclerosis in Finland 2018-data from the national register. Acta Neurol Scand. 2019. https://doi.org/ 10.1111/ane.13145.
15. Ruutiainen J, Viita AM, Hahl J, Sundell J, Nissinen $\mathrm{H}$. Burden of illness in multiple sclerosis (DEFENSE) study: the costs and quality-of-life of Finnish patients with multiple sclerosis. J Med Econ. 2016;19(1):21-33.

16. Soini E, Joutseno J, Sumelahti M-L. Cost-utility of first-line disease-modifying treatments for relapsing-remitting multiple sclerosis. Clin Ther. 2017;39: 537-57 (Soini et al. 2017).

17. Express Scripts, 2018. Express scripts 2017 drug trend report. http://lab.express-scripts.com/lab/ drug-trend-report. Accessed 8 Feb 2018.

18. Poveda JL, Trillo JL, Rubio-Terres C, Rubio-Rodriguez D, Polanco A, Torres C. Cost-effectiveness of Cladribine tablets and fingolimod in the treatment of relapsing multiple-sclerosis with high disease activity in Spain. Expert Rev Pharmacoecon Outcomes Res. 2019;25:1-9 (Epub ahead of print).

19. Hettle R, Harty G, Wong SL. Cost-effectiveness of Cladribine tablets, alemtuzumab, and natalizumab in the treatment of relapsing-remitting multiple sclerosis with high disease activity in England. J Med Econ. 2018;21:676-86.

20. Michels RE, de Fransesco M, Mahajan K, et al. Cost effectiveness of Cladribine tablets for the treatment of relapsing-remitting multiple sclerosis in The Netherlands. Appl Health Econ Health Policy. 2019. https://doi.org/10.1007/s40258-019-00500-8.

21. Soini E. Biologisten lääkkeiden kustannusvaikuttavuus nivelpsoriaasin hoidossa [Cost-effectiveness of biologic drugs in the treatment of psoriatic arthritis]. Suomalaisen Lääkäriseuran Duodecimin ja Suomen Ihotautilääkäriyhdistyksen asettama tyoryhmä [Working group of Finnish Medical Society Duodecim and Finnish Dermatologist Society]. Helsinki: Suomalainen Lääkäriseura Duodecim. Updated 2017 Mar 1. https://www.kaypahoito. fi/nix02465. Accessed 14 June 2019.

22. Soini E, Hallinen T, Laine J. Health impact modelling (HIM): concept, approach and real-world data needs for the estimation of potential effectiveness provided by a pharma company portfolio. Value Health. 2018;21:S88.

23. Soini E, Riekkinen O, Kroger $\mathrm{H}$, et al. Cost-effectiveness of pulse-echo ultrasonometry in osteoporosis management. ClinicoEcon Outcomes Res. 2018;10:279-92.

24. Social Insurance Institution. Kansaneläkelaitoksen päätös tarvittavista selvityksistä ja lääketieteellisistä edellytyksistä, joiden tulee rajoitetusti peruskorvattavan lääkkeen korvaamiseksi täyttyä [Social insurance institution's decision on the required statements and medical requirements that need to 
be fulfilled in order for person to be eligible for limited basic reimbursement] In Finnish. Updated 2019 May 28. https://www.kela.fi/documents/ 10180/23031985/Kelan\%20paatos\%20rajoitetusti\% 20peruskorvattavista\%20laakkeista\%201.11.2019\% 20\%28pdf\%29/84fc591c-8542-474c-9255-443663ef ba34. Accessed 14 June 2019.

25. Social Insurance Institution. Kansaneläkelaitoksen päätös tarvittavista selvityksistä ja lääketieteellisistä edellytyksistä, joiden tulee rajoitetusti erityiskorvattavan lääkkeen korvaamiseksi täyttyä. [Social insurance institution's decision on the required statements and medical requirements that need to be fulfilled in order for person to be eligible for limited special reimbursement] In Finnish. Updated 2019 May 28. https://www.kela.fi/documents/ $10180 / 23032230 /$ Kelan+paatos+rajoitetusti+erityis korvattavista+laakkeista+1.7.2019+\%28pdf\%29/b7 47c654-4209-4e6f-93bf-dab82b32f838. Accessed 14 June 2019.

26. Koponen P, Borodulin K, Lundqvist A, Sääksjärvi K, Koskinen S. Terveys, toimintakyky ja hyvinvointi suomessa-FinTerveys 2017 -tutkimus [Health, ability to function and welfare in Finland-FinTerveys 2017 study]. Finnish institute for health and welfare Report 4/2018, Helsinki, Finland.

27. Mauskopf JA, Sullivan SD, Annemans L, et al. Principles of good practice for budget impact analysis: report of the ISPOR task force on good research practices. Budget impoact analysis. Value Health. 2007;10(5):336-47.

28. Sullivan SD, Mauskopf JA, Augustovski F, et al. Budget impact analysis - Principles of good practice: report of the ISPOR 2012 budget impact analysis good practice II task force. Value Health. 2014;17:5-14.

29. Hospital district of Pirkanmaa. Tuottet ja hinnat 2019 [Products and prices 2019]. https://www.tays. fi/download/noname/\%7B439D0FBD-C31E-4E96B0B5-2048FC6FFD08\%7D/80188. Accessed 12 June 2019.

30. Hospital district of Uusimaa. Palveluhinnasto 2019 [Service price tariff 2019]. Available at https://www. hus.fi/hus-tietoa/talous/Hinnoittelu/Documents/ HUS\%20Palveluhinnasto\%202019.pdf. Accessed 12 June 2019.

31. Giovannoni G, Sorensen PS, Cook S, et al. Safety and efficacy of Cladribine tablets in patients with relapsing-remitting multiple sclerosis: results from the randomized extension trial of the CLARITY study. Mult Scler. 2018;24(12):1594-604.

32. Pharmaceuticals pricing board. Terveystaloudellisen selvityksen laatiminen lääkevalmisteen korvattavuus- ja tukkuhintahakemukseen, 2018
November 2018 [Guideline on preparing a health economic evaluation to be attached to the application for reimbursement status and wholesale price for a medicinal product]. In Finnish. http:// www.hila.fi/c/document_library/get_file?folderId= 792380\&name=DLFE-10630.pdf. Accessed 13 Aug 2019.

33. Fimea recommendation for the assessment of the therapeutic and economic value of pharmaceuticals. Serial Publication Fimea Develops, Assesses and Informs 2/2012. 84 p. ISBN 978-952-5624-23-6.

34. Medicinal products database. Social Insurance Institution of Finland. https://asiointi.kela.fi/ laakekys_app/LaakekysApplication?kieli=en. Accessed 2019 July 14.

35. Hospital district of Varsinais-Suomi (VSSHP). T12 Laboratoriotoimialuehinnasto 2019 [Laboratory price tariff 2019]. http://www.vsshp.fi/fi/sairaanhoi topiiri/talous-ja-toimintaluvut/hinnastot/Documents/ T12\%20Laboratoriotoimialue\%20Hinnasto\%202019. pdf. Accessed 12 June 2019.

36. Kapiainen S, Väisänen A, Haula T. Terveyden- ja sosiaalihuollon yksikkökustannukset Suomessa vuonna 2011 [Unit costs of health and social care in Finland in year 2011]. In Finnish. Finnish institute for health and welfare, Report 3/2014, Helsinki, Finland.

37. Hujanen T, Kapiainen S, Tuominen U, Pekurinen M. Terveydenhuollon yksikkökustannukset Suomessa vuonna 2006 [Unit costs of health care in Finland in year 2006]. Stakes working papers 3/2008, Helsinki, Finland.

38. Soini E, Leussu M, Hallinen T. Administration costs of intravenous biologic drugs for rheumatoid arthritis. SpringerPlus. 2013;2:531.

39. Kappos L, Radue EW, O'Connor P, et al. A placebocontrolled trial of oral fingolimod in relapsing multiple sclerosis. N Engl J Med. 2010;362:387-401.

40. Giovannoni G, Comi G, Cook S, et al. A placebocontrolled trial of oral cladribine for relapsing multiple sclerosis. N Engl J Med. 2010;362:416-26.

41. Official Statistics of Finland (OSF): Price index of public expenditure [e-publication]. Helsinki: Statistics Finland. Access method: http://www.stat.fi/til/ jmhi/index_en.html. Accessed 13 Aug 2019.

42. Official Statistics of Finland (OSF): Labour cost survey [e-publication]. 2016. Helsinki. Access method: http://www.stat.fi/til/tvtutk/2016/tvtutk_ 2016_2018-11-16_tie_001_en.html. Accessed 13 Aug 2019. 
43. Fleurence RL, Hollenbeak CS. Rates and probabilities in economic modelling. Pharmacoeconomics. 2007;25(1):3-6.

44. Polman $\mathrm{CH}, \mathrm{O}^{\prime}$ Connor PW, Havrdova E, et al. A randomized, placebo-controlled trial of natalizumab for relapsing multiple sclerosis. N Engl J Med. 2006;354:899-910.

45. Soini E, Hallinen T, Sokka AL, Saarinen K. Costutility of first-line actinic keratosis treatments in Finland. Adv Ther. 2015;32:455-76.

46. Mankinen P, Soini E, Linna M, Turunen J, Martikainen J, Laine J. Näkökulma vaikuttaa terveysteknologioiden taloudellisen arvioinnin tuloksiinesimerkkinä iäkkäiden pneumokokkirokottaminen [Perspective impacts the results of health technology assessment-pneumococcal vaccination of the Finnish elderly]. Dosis. 2019;35(2):118-35 (Mankinen et al. 2019a).

47. Mankinen P, Vihervaara V, Torvinen S, Martikainen J, Soini E. Costs of administration, travelling, and productivity losses associated with hospital administration of multiple myeloma drugs in Finland. J Med Econ. 2019;22(4):328-35 (Mankinen et al. 2019b).

48. Williamson EML, Berger JR. Diagnosis and treatment of progressive multifocal leukoencephalopathy associated with multiple sclerosis therapies. Neurotherapeutics. 2017;14:961-73.

49. Ho PR, Koendgen H, Campbell N, Haddock B, Richman S, Chang I. Risk of natalizumab-associated progressive multifocal leukoencephalopathy in patients with multiple sclerosis: a retrospective analysis of data from four clinical studies. Lancet Neurol. 2017;16(11):925-33. https://doi.org/10. 1016/S1474-4422(17)30282-X (Epub 2017 Sep 29).

50. Siddiqui MK, Khurana IS, Budhia S, Hettle R, Harty G, Wong SL. Systematic literature review and network meta-analysis of Cladribine tablets versus alternative disease-modifying treatments for relapsing-remitting multiple sclerosis. Curr Med Res Opin. 2018;34(8):1361-71.

51. Kalincik T, Jokubaitis V, Spelman T, et al. Cladribine versus fingolimod, natalizumab, and interferon $\beta$ for multiple sclerosis. Mult Scler. 2018;24(12): 1617-26.

52. Berardi A, Siddiqui MK, Treharne C, Harty G, Wong SL. Estimating the comparative efficacy of Cladribine tablets versus alternative disease modifying treatments in active relapsing-remitting multiple sclerosis: adjusting for patient characteristics using meta-regression and matching-adjusted indirect treatment comparison approaches. Curr Med Res Opin. 2019;35(8):1371-8.

53. Väätäinen S, Soini E, Arvonen S. Digitalization and customer-responsive secondary care services potentially free health care capacity: predicted monetary benefits of virtual hospital 2.0. Value Health. 2018;21(suppl 3):S151.

54. ESiOR. Kohti terveyttä edistävää Suomea 2030. StopDia-investointilaskurin tulosraportti [Towards health promoting Finland. StopDia-result report of the investment calculator]. Version 1. 0. https://esior.io/stopdialaskuri1/. Accessed 25/09/ 2019.

55. ESiOR. StopDia-investointilaskuri tyypin 2 diabeteksen ehkäisyn terveystaloudellisten vaikutusten arviointiin [StopDia investment calculator for the assessment of health economic effects related to the prevention of type 2 diabetes]. ESiOR Oy: Application, 21.8.2019. https://esior.io/ stopdialaskuri1/. Accessed 25 Sept 2019.

56. Väätäinen S, Soini E, Arvonen S, Suojanen L, Pietiläinen $\mathrm{KH}$. Potential direct secondary care cost benefits of HealthyWeightHub-virtual hospital 2.0 digital lifestyle intervention. Finnish $\mathrm{J}$ eHealth eWelfare (FinJeHeW). 2019;11:342-56. 